\title{
PENGARUH PEMBERIAN EKSTRA ETHANOL DAUN TITHONIA DIVERSIFOLIA, EKSTRA ALLIUM SATIVUM dan CAMPURAN EKSTRA ALLIUM SATIVUM TERHADAP KERUSAKAN HISTOLOGI GINJAL dan HATI MENCIT HIPERGLIKEMIA
}

\author{
${ }^{(1)}$ Eka.P.F dan ${ }^{(2)}$ Sukarjati
}

(1) Mahasiswa Prodi Biologi F.MIPA Universitas PGRI Adi Buana Surabaya

(2) Staf Pengajar Prodi Biologi F.MIPA Universitas PGRI Adi Buana Surabaya Email: ${ }^{(2)}$ sukarjati@ymail.com

\begin{abstract}
Tithonia diversifolia and allium sativum are believed by the community to lower blood sugar levels. Research on safety test of Tifonia diversifolia extract and Allium sativum to histology of liver and kidney has not been done. The purpose of this research was to find out the effect of trimonic diversifolia extract extract and Allium extract as well as the extract and the second leaf mixture to histology structure of kidney and liver of mice with diabetes.This study was an experimental study in 45 mice sampled in divided into 11 groups of control groups extract tithonia diversifolia $50 \mathrm{mg} / \mathrm{kg} \mathrm{bb}, 100 \mathrm{mg} / \mathrm{kgbb}$ and $150 \mathrm{mg} / \mathrm{kg} \mathrm{bb}$. As well as Alium sativum extract 50 $\mathrm{mg} / \mathrm{kg} \mathrm{bb} 100 \mathrm{mg} / \mathrm{kgbb}$ and $150 \mathrm{mg} / \mathrm{kg} \mathrm{bb}$ and mixed extract of tithonia diversfolia and Allium sativum C2 25:25 mg/ kgbb, C3 50:50 mg/ $\mathrm{kg} \mathrm{bb} \mathrm{And} \mathrm{75:75} \mathrm{mg} / \mathrm{kg} \mathrm{bb}$. And administration of chlamydial gliben. The extract was administered for 35 days, after which surgery and preparation of histology of kidney and liver of mice Furthermore, the result he analyzed using spss Anova one way and descriptive analysis The results of this study showed no significant differences in the control group $(P=1,000)$, Treatment of Tithonia diversifolia extract Dose 50mg / $\mathrm{kgbb}(P=1.00)$, dose $100 \mathrm{mg} / \mathrm{kgbb}(P=1.00)$, dose $100 \mathrm{mg} / \mathrm{kgbb}(P=1.00)$ Dose $150 \mathrm{~m} / \mathrm{kgbb}(P=1.00) \mathrm{Kgbb}$ $(P=1.00)$ and mixed dosage 25: $25 \mathrm{mg} / \mathrm{kgbb}(0.111)$ but significant with 50:50 mixed significantly differentiated doiss treatments $(P=0.003)$ and $C 4$ mixture extract $(0.000)$ on liver histology On histology of the liver. While on the histology of the kidney,perlakuan Ekstrak Tithonia diversifolia dosis 50mg/kgbb,dosis $100 \mathrm{mg} / \mathrm{kgbb}, 150 \mathrm{mg} / \mathrm{kgbb}$ serta perlakuan esktrak Allium sativum dosis 50mg/kgbb,dosis $100 \mathrm{mg} / \mathrm{kgbb} 150 \mathrm{mg} / \mathrm{kgbb}$ also extracts Tithonia diversifolia mixture and Allium sativum extract dose 25:25 mg/ kgbb 50:50 dose and 75:75 does not affectthe histology of renal mice Conclusion: There is a mild hemorrhage to the liver in all treatments of tithonia extract, Allium sativum, or mixture.
\end{abstract}

Keywords:Tithonia diverifolia,Allium Sativum,Histologic of hepar and kidney of mice

\section{PENDAhUluan}

Menurut Internasional of Diabetic Ferderation (IDF, 2015) tingkat prevalensi global penderita DM pada tahun 2014 sebesar $8,3 \%$ dari keseluruhan penduduk di dunia dan me ngalami peningkatan pada tahun 2014 menjadi 387juta kasus. Indonesia merupakan negara menempati urutan ke 7 dengan penderita DM sejumlah 8,5 juta penderita setelah Cina, India dan Amerika Serikat, Brazil, Rusia, Mexico. Angka kejadian DM menurut data Riskesdas (2013) terjadi peningkatan dari 1,1\% di tahun 2007 meningkat menjadi $2,1 \%$ di tahun 2013 dari ke seluruhan penduduk sebanyak 250 juta jiwa.
Penggunaan ekstrak daun Tithonia diversifoliadan Allium sativummempunyai efek signifikan terhadap penurunan kadar glukosa terhadap Penyakit diabetes type II.Dan juga penelitian yang dilakukan Ronal pasaribu dkk (2013), daun Tithonia diversifolia mampu menurunkan kadar gula darah mencit. Ekstrak rebusan daun berpengaruh terhadap penurunan kadar glukosa darah tikus DM terutama rebusan daun dewasa yang menurunkan kadar glukosa darah mencapai $71,16 \%$. Daun Tithonia diversifolia terbukti mampu menurunkan kadar glukosa darah.(Rinawati, 2016)

Data mengenai uji keamanan ekstrak daun Tithonia diversifoliadan Allium 
sativummasih sangat sedikit bahkan belum ada.namun berdasarkan penelitan Nuri dkk 2008, uji toksisitas mengenai perubahan kadar ureum dan kreatinin pasca pemberian ekstrak etanol daun Tithonia diversifolia menunjukan tidak terdapat perbedaan yang signifikan kadar kreatinin dan ureum antara kontrol dan kadar kreatinin mencit yang telah diberikan ekstrak daun Tithonia diversifolia

kurang lebih 10 Efek racun dari obat sebagian besar terdeteksi dalam jaringan hati dan ginjal. Hati adalah organ pertama yang berpotensi menderita keracunan sebelum organ lain. Ginjal merupakan jalur utama ekskresi dan penyaringan darah. Oleh karena itu, ginjal dan hati adalah organ yang sebagian besar dipengaruhi oleh senyawa beracun.(Setyowati ayu, 2015)

Karena itu setiap penggunaan obat tradsional perlu dilakukan pengujian agar penggunaan nya tidak menimbulkan efek dan aman bagi pemakainya, Berdasarkan uraian di atas peneliti tertarik untuk meneliti pengaruh pemberian ekstrak daun Tithonia diversifolia pada mencit yang menderita diabetes, terhadap struktur histologi ginjal dan hati mencit .

\section{MATERI DAN METODE PENELITIAN}

Populasi penelitian ini adalah mencit jantan sehat berumur 2-3 bulan dengan bobot $20-30$ gram yang diperoleh dari Pusvetma Surabaya,dan Sampel pada penelitian inia dalah preparat histologi ginjal dan hati mencit yang berasal dari tiap kelompok perlakuan.pada penelitian ini jumlah mencit yag digunakan adalah 45 yang terdiri dari 15 perlakuan dengan 3 kali pengulangan.

\section{Persiapan alat dan bahan}

Dalam penelitian ini menggunakan daunTithonia diversifoliamenggunakan umbi Allium sativum, Alat yang digunakan adalah Timbangan, seperangkat alat ekstrak,gelas ukur,rotary evapatory)

\section{Uji Pendahuluan}

Sebanyak 45 ekor mencit jantan di bagi menjadi kelompok yang terdiri dari $(\mathrm{A} 1, \mathrm{~B} 1, \mathrm{C} 1)$ sebagai kontrol negatif dan perlakuan glibenklamid (A5,B5,C5) kelompok perlakuan ekstrak (A2,A3,A 4,B2,B3,B4,C2,C3,C4) Perlakuan tiap kelompok sebagai berikut: Kelompok (A1,B1,C1) sebagai kelompok kontrol yag tidak diberikan perlakuan ekstrak daun Tithonia diversifolia, ekstrak Alium sativum maupun campuran ekstrak keduanya.Kelompok A2 diberikan perlakuan ekstrak daun Tithonia diversifolia $50 \mathrm{mg} / \mathrm{kg}$ bb selama 35 hari Kelompok A3 diberikan perlakuan ekstrak daun Tithonia diversifolia $100 \mathrm{mg} / \mathrm{kg}$ bb selama 35 hari, Kelompok A4 diberikan perlakuan ekstrak daun Tithonia diversifolia $\quad 150 \quad \mathrm{mg} / \mathrm{kg} \quad$ bb selama 35 hari,Kelompok B2 diberikan perlakuan ekstrak Alium sativum $50 \mathrm{mg} / \mathrm{kg}$ bb selama 35 hari,Kelompok B3 diberikan perlakuan ekstrak Alium sativum $100 \mathrm{mg} / \mathrm{kg}$ bb selama 35 hari,Kelompok B4 diberikan perlakuan ekstrak Alium sativum $150 \mathrm{mg} / \mathrm{kg}$ bb selama 35 hari ,Kelompok C2 diberikan perlakuan ekstrak campuran daun Tithonia diversifolia dan ekstrak Alium sativum 25:25, Kelompok C3 diberikan perlakuan ekstrak campuran daun Tithonia diversifolia dan ekstrak Alium sativum 50:50,Kelompok C3 diberikan perlakuan ekstrak campuran daun Tithonia diversifolia dan ekstrak Alium sativum 50:50 Kelompok C4 diberikan perlakuan ekstrak campuran daun Tithonia diversifolia dan ekstrak Alium sativum 50:50

\section{Tahap perlakuan pada hewan coba}

Pemberian Ekstrak daunTithonia diversifolia,dan Alium sativum dan kombinasi antar Ekstrak kedua daun tersebut, dilarutkan dengan Aquadest.ekstrak diberikan secara oral menggunakan sonde dengan Volume integretis mencit $(1 \mathrm{ml})$. ekstrak diberikan kepada mencit sekali sehari selama 35 hari dengan dosis yang telah dihitung sesuai dengan $\mathrm{mg} / \mathrm{kg}$ bb mencit,pada hari ke 36 dilakukan dekapitasi pada mencit dengan cara dislokasi leher.setelah di dekapitasi dilakukan pengambilan organ ginjal da hati ,kemudian dibuat preparat histology ginjal dan preparat histology hati dan selanjutnya dilakukan pewarnaan hematoxylineosin terjadap masing masing preparat. 


\section{HASIL PENELITIAN Hasil Histologi Ginjal}

Data kerusakan histologi hati pada mencit kelompok kontrol (A1, B1, C1) dan kelompok mencit yang diberi ekstrak Tithonia diversifolia dosis $\quad 50 \mathrm{mg} / \mathrm{kg} \quad$ bb $\quad$ (A2), $100 \quad \mathrm{mg} / \mathrm{kg} \quad$ bb (A3), $150 \mathrm{mg} / \mathrm{kg}$ bb (A4) dan ekstrak Kelompok mencit yang diberi ekstrak Allium sativum Dosis $50 \mathrm{mg} / \mathrm{kg} \quad$ bb (B2),100 $\mathrm{mg} / \mathrm{kg} \quad$ bb (B3), $150 \mathrm{mg} / \mathrm{kg}$ bb (B4) Serta campuran ekstrak Tithonia diversifolia dan ekstrak Allium sativum dosis $25: 25 \mathrm{mg} / \mathrm{kg}$ bb (C1), dosis 50:50 mgkg bb (C3) Dosis 75:75 mg/kgbb disajikan dalam diagram dan Tabel 1.

Tabel 1. Hasil pemeriksaan histologi hati

\begin{tabular}{|c|c|c|c|c|}
\hline \multirow[t]{2}{*}{ No } & \multirow{2}{*}{$\begin{array}{l}\text { Kode } \\
\text { sampel }\end{array}$} & \multicolumn{3}{|c|}{ parameter } \\
\hline & & $\begin{array}{l}\text { Degener } \\
\text { asi } \\
\text { lemak }\end{array}$ & $\begin{array}{l}\text { Hemorrh } \\
\text { age }\end{array}$ & nekrosis \\
\hline 1 & A1 & 0 & 1 & 0 \\
\hline 2 & A2 & 0 & 1 & 0 \\
\hline 3 & A3 & 0 & 1 & 0 \\
\hline 4 & A4 & 0 & 1 & 0 \\
\hline 5 & A5 & 0 & 1 & 0 \\
\hline 6 & B1 & 0 & 1 & 0 \\
\hline 7 & B2 & 0 & 1 & 0 \\
\hline 8 & B3 & 0 & 1 & 0 \\
\hline 9 & B4 & 0 & 1 & 0 \\
\hline 10 & B5 & 0 & 1 & 0 \\
\hline 11 & C1 & 0 & 1 & 0 \\
\hline 12 & $\mathrm{C} 2$ & 1 & 1 & 0 \\
\hline 13 & $\mathrm{C} 3$ & 1 & 1 & 0 \\
\hline 14 & $\mathrm{C} 4$ & 1 & 1 & 0 \\
\hline 15 & $\mathrm{C} 5$ & 0 & 1 & 0 \\
\hline
\end{tabular}

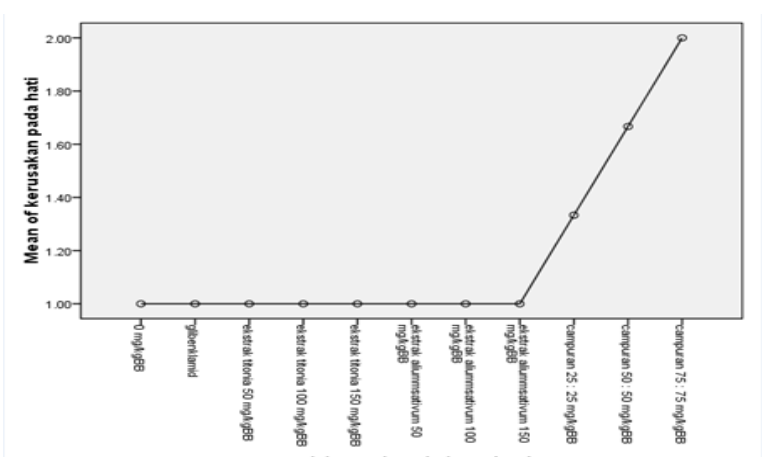

Pada Diagram 1 menunjukkan bahwa pemberian campuran ekstrak Tithonia diversifolia dan Ekstrak Allium sativum dengan ,dosis 50:50 dan juga dosis 75:75 berpengaruh signifikan terhadap kondisi seluler hati. Namun, pemberian secara tunggal ektrak Tithonia difersivoli dan Ekstrak Allium sativum dengan masing-masing dosis $50 \mathrm{mg} / \mathrm{kg}$ bb, dosis 100 $\mathrm{mg} / \mathrm{kg} \mathrm{bb}$, dosis $150 \mathrm{mg} / \mathrm{kg}$ tidak memberi pengaruh secara signifikan terhadap perubahan seluler hati hewan coba. Perubahan yang terjadi yaitu degenerasi lemak dan hemorrhage (perdarahan) yang ditunjukkan dengan skor 1 . Skor tersebut menandakan tingkat degenerasi lemak danhemorrhage yang terjadi hanya 25$50 \%$ per lapang pandang.

\section{Hasil Histologi Ginjal}

Data kerusakan histologi ginjal pada mencit kelompok kontrol (A1, B1, C1) dan kelompok mencit yang diberi ekstrak Tithonia diversifolia dosis $\quad 50 \mathrm{mg} / \mathrm{kg} \quad$ bb $\quad$ (A2), $100 \quad \mathrm{mg} / \mathrm{kgbb}$ (A3), $150 \mathrm{mg} / \mathrm{kg}$ bb (A4) dan kelompok mencit yang diberi ekstrak Allium Sativum dosis $50 \mathrm{mg} / \mathrm{kg}$ bb (b2), $100 \mathrm{mg} / \mathrm{kgbb}$ (B3), $150 \mathrm{mg} / \mathrm{kg}$ bb (B4). Serta pemberian campuran ekstrak Tithonia diversifolia dan ekstrak Allium sativum dosis 25:25 mg/kgbb (C1),Dosis 50:50 mgkgbb (C3) Dosis 75:75 mg/kgbb disajikan dalam Tabel 2 dan Diagram 1. 
Tabel 2. Hasil Pemberian Beberapa Macam Estrak Pada Berbagai Dosis Terhadap Kerusakan Ginjal

\begin{tabular}{|c|c|c|c|c|}
\hline \multirow[t]{2}{*}{ no } & \multirow{2}{*}{$\begin{array}{l}\text { Kode } \\
\text { sampel }\end{array}$} & \multicolumn{3}{|c|}{ parameter } \\
\hline & & $\begin{array}{l}\text { radang } \\
\text { interstitia } \\
1\end{array}$ & $\begin{array}{c}\text { Fibrosis } \\
\text { gllomeru } \\
\text { lus }\end{array}$ & $\begin{array}{l}\text { Atrofi } \\
\text { tubulus }\end{array}$ \\
\hline 1 & A1 & 0 & 0 & 0 \\
\hline 2 & A2 & 0 & 0 & 0 \\
\hline 3 & A3 & 0 & 0 & 0 \\
\hline 4 & A4 & 0 & 0 & 0 \\
\hline 5 & A5 & 0 & 0 & 0 \\
\hline 6 & B1 & 0 & 0 & 0 \\
\hline 7 & B2 & 0 & 0 & 0 \\
\hline 8 & B3 & 0 & 0 & 0 \\
\hline 9 & B4 & 0 & 0 & 0 \\
\hline 10 & B5 & 0 & 0 & 0 \\
\hline 11 & $\mathrm{C} 1$ & 0 & 0 & 0 \\
\hline 12 & $\mathrm{C} 2$ & 0 & 0 & 0 \\
\hline 13 & C3 & 0 & 0 & 0 \\
\hline 14 & $\mathrm{C} 4$ & 0 & 0 & 0 \\
\hline 15 & $\mathrm{C} 5$ & 0 & 0 & 0 \\
\hline
\end{tabular}

Pada Tabel 2 menunjukkan bahwa pemberian secara tunggal ektrak Tithonia difersivoli dan Ekstrak Allium sativum dengan masing-masing dosis $50 \mathrm{mg} / \mathrm{kg} \mathrm{bb}$, dosis 100 $\mathrm{mg} / \mathrm{kg} \mathrm{bb}$, dosis $150 \mathrm{mg} / \mathrm{kg}$ dan pemberian campuran ekstrak Tithonia diversifolia dan Ekstrak Allium sativum dengan dosis 25:25 ,dosis 50:50 dan juga dosis 75:75 tidak memberi pengaruh secara histologist terhadap perubahan seluler hati hewan coba.

\section{PEMBAHASAN}

\section{Pembahasan Hati}

Hati merupakan organ tubuh yang paling rentan terkena bahan kimia toksik.yang pada pemeriksaan histologi tampak degenerasi lemak, nekrosis hati, karena merupakan tempat metabolisme utama yang akan mendetoksifikasi dan mengeliminasi semua toksin baik endogen ataupun eksogen (Crawford, 2005) . Sehingga apabila terjadi kerusakan pada hati, maka dapat menyebabkan metabolism sel terganggu. Gangguan yang tampak pada penelitian yaitu adanya perdarahan (hemorrhage) dan degenerasi lemak pada sel hati.
Hemorrhage terjadi pada kelompok kontrol dan semua sampel perlakuan. Pada kelompok kontrol,Proses ini disebabkan oleh stress atau trauma dalam bentuk fisik yang merusak system vaskula jaringan,hormone kartisol akan meningkat akan menekan poliverasi leukosit sehingga imunitas berkurang,daya tahan tubuh berkurang, Pada kelompok perlakuan oleh hiperglikemia yang menyebabkan plak pada pembuluh darah, sehingga menyebabkan perdarahan pembuluh darah hati. Ini ditegaskan oleh pernyataan ADA (2012) Diabetes mellitus berhubungan dengan hiperglikemia yang bisa menyebabkan kerusakan jangka panjang pada mata, syaraf, pembuluh darah dan ginjal. Selain itu, diabetes mellitus berhubungan langsung dengan Hipertensi. Hipertensi porta yang diakibatkan oleh peningkatan tahanan yang berupa hiperglikemia ke aliran porta dan banyaknya darah yang masuk ke vena porta. Mekanisme ini menjadi perdarahan akibat pecahnya pembuluh darah.

Hemorrhage terjadi pada kelompok mencit yang diberikan ekstrak Tithonia diversifolia dengan dosis $50 \mathrm{mg} / \mathrm{kg}$, dosis $100 \mathrm{mg} / \mathrm{kg}$ serta dosis $150 \mathrm{mg} / \mathrm{kg}$ dan juga tidak ada perbedaan signifikan terhadap perlakuan Ekstrak Allium sativum dosis $50 \mathrm{mgn} / \mathrm{kg} \mathrm{bb}$, dosis $100 \mathrm{mg} / \mathrm{kg}$ $\mathrm{bb}$ dan juga dosis $150 \mathrm{mg} / \mathrm{kg}$ serta dosis campuran keduanya. Ini disebabkan karena akibat dari zat Aloksan serta yang diberikan ekstrak yang diberikan sehingga menyebabkan diabetes mellitus pada hewan coba dan ekstrakaktrak tersebut berperan langsung terhadap perdarahan hati.

Degenerasi lemak sel terjadi pada pemberian campuran daun Tithonia diversifolia dan ekstrak Allium sativum dengan dosis 50:50 $\mathrm{mg} / \mathrm{kgbb}$ dan dosis $75: 75 \mathrm{mg} / \mathrm{kgbb}$. Hal ini karena kombinasi ekstrak kedua daun tersebut yang dapat meningkatkan aktivitas zat yang lebih kuat. Seperti yang diketahui berdasarkan penelitian Suyati (2014). Asam amino tinggi yang terdapat dalam Allium sativum dapat menyebabkan degenerasi lemak. Flavonoid dosis tinggi pada ekstrak Tithonia diversifolia menimbulkan adanya degenerasi lemak pada sel. Perlakuan ekstrak campuran daun Tithonia 
diversifolia dan ekstrak Allium sativum yang mengadung asam amino dan flavonoid tinggi berperan langsung dalam proses degenerasi sel. Degerenasi merupakan perubahan morfologi sel yang bersifat reversible disebabkan oleh beberapa faktor salah satu nya adalah keracunan ini di tandai dengan lemak tertimbun di sitoplasma, sitoplasma membesar,ini ketepi,karena adanya akumulasi dari beberapa produk dari hasil metabolism seperti air, lemak, protein, glikogen dan sebagainya

\section{Pembahasan Ginjal}

Ginjal merupakan salah satu organ yang terkena efek toksisitas jika tubuh terpapar oleh antinutrisi dan mudah mengalami kelainan sehingga berampak secara morfologis dan fungsional sehingga terjadi kerusakan.kerusakan dapat , proliferasi sel ,infiltrasi sel radang dan lain lain (Nur assiam, Iriani stetyawati, 2014).

Pada Penelitian ini tidak terdapat kerusakan histologi ginjal pada perlakuan ekstrak Tithonioa diversifolia doisis $50 \mathrm{mg} / \mathrm{kg}$, dosis $100 \mathrm{mg} / \mathrm{kg}$ serta dosis $150 \mathrm{mg} / \mathrm{kg}$ dan perlakuan ekstrak Allium sativum dosis $50 \mathrm{mg} / \mathrm{kg}$ bb, dosis $100 \mathrm{mg} / \mathrm{kg}$ bb dan serta dosis $150 \mathrm{mg} / \mathrm{kg}$ serta campuran daun Tithonia diversifolia dan ekstrak Allium sativum dosis $25: 25 \mathrm{mg} / \mathrm{kgbb}$, dosis $50: 50 \mathrm{mg} / \mathrm{kgbb}$ dan dosis $75: 75 \mathrm{mg} / \mathrm{kgbb}$. Hal ini terlihat dari perlakuan yang tidak terdapat ciri-ciri sel yang mengalami atrofi tubulus, fibrosis glomerulus dan radan interstitial artinya ekstrak Tithonia diversifoliatidak menimbulkan kerusakan pada histologi ginjal mencit. Pada penelitian terdahulu (Febrian, 2013) melihat pengaruh ekstrak Tithonia diversifolia terhadap kadar ureum dan kreatinin (fungsi ginjal) menunjukan tidak terdapat pebedaan kadar ureum dan kreatinin pada mencit setelah pemberian ekstrak Tithonia diversifolia. Pada ekstrak Allium sativum juga menunjukan hal yang sama yaitu tidak terdapat kerusakan pada histologi ginjal dalam bentuk atrofi tubulus, fibrosis glumerulus maupun radang intestitial.

Tidak adanya kerusakan secara langsung akibat penambahan ektraksi menunjukkan bahwa ginjal masih mampu mentolerir kerusakan pada hati, sehingga tidak berdampak pada ginjal. Ini diperkuat oleh penelitian Aningdyaningtias (2013) yang menunjukkan ekstak Tithonia diversifolia tidak berpengaruh pada kadar kreatinin dan berpengaruh pada histologi ginjal seperti peradangan hanya pada dosis tinggi yaitu 2000 $\mathrm{mg} / \mathrm{kgbb}$. Dapat disimpulkan bahwa penggunaan ektrak Tithonia diversifolia dan Allium sativum serta campuran keduanya tidak menimbulkan dampak pada sel ginjal dengan dosis tertentu.

Secara keseluruhan dapat disimpulkan Tithonia diversifolia dan Allium sativum dengan dosis $50 \mathrm{mg} / \mathrm{kg}$, dosis $100 \mathrm{mg} / \mathrm{kg}$ serta dosis 150 $\mathrm{mg} / \mathrm{kg}$ tidak menyebabkan kerusakan pada sel ginjal. Namun, campuran Tithonia diversifolia dan Allium sativum dengan dosis $50: 50 \mathrm{mg} / \mathrm{kgbb}$ dan dosis $75: 75 \mathrm{mg} / \mathrm{kgbb}$ berdampak langsung pada degenerasi lemak sel hati. Zat yang berperan dalam degenerasi lemak sel adalah asam amino pada Tithonia diversifolia dan flavonoid pada Allium sativum. Stadium degenerasi lemak dan perdarahan yang terjadi masih pada tahap sedang. Sehingga penggunaan dosis yang tepat tidak akan mengganggu fungsi sel hati maupun ginjal

\section{KESIMPULAN}

1.Tidak ada pengaruh pemberian ekstrak Tithonia diversifolia terhadap kerusakan ginjal dan hati mencit.

2.Tidak ada pengaruh pemberian ekstrak Alium sativum terhadap kerusakan ginjal dan hati mencit.I

3.Tidak ada pengaruh pemberian ekstrak campuran Tithonia diversifolia danAlium sativum terhadap kerusakan ginjal mencit.

4.Ada pengaruh pemberian ekstrak campuran Tithonia diversifolia danAlium sativum terhadap kerusakan hati mencit

\section{DAFTAR PUSTAKA}

Alatas.H.,Tambunan. 2002.Buku Ajar Nefrologi. Ikatan Dokter Indonesia. Jakarta 
Amanaitie,Sulistyowati Eddy. 2015. Structure Eluctidation Of The Leaf Of Tithonia Diversifolia.State University,Yogakarta

Asri Sulistojowati,Gunawan Didik . 2001. Tithonia Deversifolia Terhadap Candida Albican.Badanoenelitian Dan Pengembangan Kesehatan,Jakarta

Cabdrasoma, Taylor Robins. 2005. The Biologi Bulletin. Newyork

Guyton. A,Har.J.E. 2007. Buku Ajar Fisiologi Kedokteran. Jakarta.Penerbit Buku Kedokteran Egc

Juin Quiera,Carnero,J. 1991.Histologi Dasar Edisi 3. Histologi Dasar Edisi 3. Jakarta. Penerbit Buku Kedokteran Egc

Hernawan Eko,Setyawan Ahmad. 2003. Senyawa Organosulfur Bawang Putih(Alium Sativum) Dan Aktivitas Biologinya.Universitas Negri Surakarta

Malole Mbm,Csu Pramuno. 1989.Penggunaan Hewan Laboratorium. Departemen Pendidikan Dan Kebudayaan.Bogor

Mangkowidjojo. 1988. Buku Ajar Diabetes Universitas Gadjamada.Yogyakarta

Mathew B.C.,Augsti K.T. 2003. Studies On The Effect Of Garlic. Hypoglicemia Action En Enchacement Of Serum Insulin.India

Rinawati 2013 Pengaruh Ekstrak Tithonia Diversiolia

Suyanti L .2008. Gambaran Histopatologi Hati Dan Ginjal Tikus Pada Pemberian Fraksi Asam Amino Non Protein Lamtoro Merah (Acacila Villosa) Pada Uji Toksisitas Akut.Skipsi.Bogor.Fakultas

Kedokteran Hewan Institut Pertanian Bogor

Susianti. 2013. Pengaruh Ekstrak Jinten Hitam (Nigella Sativa L) Terhadap Kerusakan Sel Tubulus Proksimal Ginjal Tikus Putih(Rattus Norvegicus) Jantan Galur Sparague Dawley Yang Diinduksi
Gentamisin.Jurnal Kdokteran Dan Kesehatan Universitas Lampung

Siregar. 2011. Tumbuhan Kembang Bulan.Instutional Respository. Sumatra Utara

Titik Jayanti. 2010. Tumbuhan Tithonia Diversiolia. Universitas Airlangga. Surabaya 